\title{
Comparative Study on the Artistic Expression Techniques of Sino-Russian Ice and Snow Painting*
}

\author{
Lei Song \\ Heihe University \\ Heihe, China 164300
}

\begin{abstract}
When people talk about the composition of ice and snow painting, they would easily believe that it is the problem of artistic expression techniques. This may be influenced by some western schools of oil painting landscape creation theory. The composition of Sino-Russian ice and snow paintings is the unity of creative content and artistic expression technique. This is different from the view of some schools in the West. In the new era, with the proposal of China's "the Belt and Road", China and Russia are strengthening cooperation and cultural exchanges in politics, economy, art and other aspects. The comparative study on the artistic expression techniques of Sino-Russian ice and snow paintings has become the main research project of current art creation for Chinese and Russian oil paintings.
\end{abstract}

Keywords-ice and snow painting; artistic expression technique; comparative study

\section{INTRODUCTION}

In the view of materialist dialectics, the artistic expression and creative content of Sino-Russian ice and snow paintings are relative concepts. The artistic expression techniques and creative content of Sino-Russian ice and snow paintings cannot exist independently. They can only exist in the unity. There is no artistic expression separating from the creative content for Sino-Russian ice and snow painting. And there is no content separating from the artistic expression. Marx said: "If the expression technique doesn't refer to the expression of the content. It would have no value." As for the creation content and the artistic expression of Sino-Russian ice and snow paintings, the creation content plays decisive role. The artistic expression techniques and creative content of Sino-Russian ice and snow paintings are mutually restricted on this basis.

\section{THE RELATIVE INDEPENDENCE OF ARTISTIC EXPRESSION TECHNIQUE OF SINO-RUSSIAN ICE AND SNOW PAINTINGS}

The composition of Sino-Russian ice and snow painting is the organic unity of content and expression technique. In this organic unity, we cannot ignore the positive role of the artistic expression of ice and snow paintings. The expression

*This article is supported by Youth Project of Heilongjiang Philosophy and Social Science Research Planning, "Comparative Study of the Artistic Expression Techniques of Sino-Russian ice and snow painting". Project number: 16YSC01. technique is positive. It does not depend on the content of the picture, and it also has the influences on the content. For example, when the ice and snow painters are committed to creative expression techniques, they also ponder and refine the content of the ice-snow works. Finally, the overall content of the picture would be perfect. However, when the content of the picture is embodied in the expression technique, there will be contradictions between them in addition to the unification of the expression technique and the content. The reason why this kind of contradiction arises is that the expression technique is relatively independent. It is within the unity of expression technique and content. Also, it is constrained by the content.

The relative independence of this relative art expression technique of Sino-Russian ice and snow painting is first manifested in the historical development of ice and snow art. The development of expression techniques may lag behind the development of content. The new content always leads to expression in one way or another. The changes have prompted the emergence of new features in the expression of ice and snow. However, in the beginning stage of creating new expression and new content of ice and snow painting, it is also possible to use the factors of the old expression techniques associated with the old content, and the characteristics of the used old expression techniques will gradually disappear. In the history of art, we should avoid confusing expression techniques with content, and also prevent the relative independence of expression technique from becoming one-sided view of absolute independence. The former one would discard content to replace the content with the expression. The latter one separates the content from the expression. Ultimately, it would lead to expressionism.

\section{THE INTEGRITY OF EXPRESS TECHNIQUE OF ART COMPOSITION OF SINO-RUSSIAN ICE AND SNOW PAINTING}

For the aesthetic characteristics of Sino-Russian ice and snow painting, the image and composition expression should be vivid, distinct and typical. Also, it should maintain its integrity. That is to say, the local and the whole should be harmonious and unified. Belinsky pointed out: "The work embraces and infiltrates all of your life, and its parts are vivid and unforgettable when they are connected with the whole." The true Sino-Russian ice and snow painters are good at feeling the whole, and are good at feeling the dependence of all the expression elements of ice and snow 
on the overall picture. He can see infinite variety of color changes. Combining with the form and the vivid sparkle of light and shadow, he would view them. The composition expression of whole snow and ice painting should be a harmonious unity. The various parts of the ice and snow painting are interrelated and echoed, which is the diverse unity of ice and snow creation. This is reasonable and perfect structural representation of things.

What needs to be taught in the teaching of art composition of Chinese ice and snow painting is the correct understanding of the integrity of the overall ice and snow picture, as well as the perfection of the thought and composition expression of the ice and snow painting. This is the performance of reasonable and perfect structure of things. In the creation of Chinese ice and snow paintings, the composition is "complete and perfect". In the composition of "setting the location" and "displaying the power", the painter should have a well-thought-out plan, "abandon the complex chapters and take the abstract". The artistic creation of Chinese ice and snow paintings has always taken the first principle of "rhythmic vitality", "unity of form and spirit", "writing "form" by means of "spirit" and "seeking similarity in spirit". Otherwise, it is impossible to achieve the "integrity and perfection" of the composition and expression of ice and snow painting. The integrity of the composition depends on the interrelationship of all its factors, and this connection should depend on the logic of the development of the mind. The integrity refer to integrity in form and spirit.

The composition expression technique of art creation of Russian ice and snow painting should also be complete. And the integrity of composition does not refer to the completeness of the expression technique, or even the misunderstanding that the fragment composition is incomplete. And the integrity of composition expression technique of Russian ice and snow painting art creation is first expressed in the author's clear theme, and high standard requirements in the process of the entire composition. For the integrity of the composition, the painter should regard the picture as a unified whole. This is one of the most important laws of Russian plastic arts. What should be left in the structure expression technique of Russian ice and snow painting art creation is not the dispensable spots, lines and images, or accidental things that have nothing to do with the ideological content of the works. Every detail on the composition should be necessary. What is indispensable is the organic connection with the theme of the work. The main and secondary features on the screen are mutually appropriate. The partial obedience to the whole and the secondary obedience to the subject are inseparable. It is an indivisible organism. The composition of the Russian ice and snow painting art creation would leave people obvious and perfect impression. It is balanced and changing, contrasting and echoing. The correct composition should first stipulate the viewer's sensory logic to make it consistent with the logic of the artist's thought development. In the composition, if the wrangling guest robs the place of the host, the secondary things will affect the performance of the subject. It will destroy the integrity of the composition. The integrity of the composition is not only reflected in the psychological connection of the characters, but also in the structure of the expression technique. The composition does not allow the "background" that does not work and the colors and lines that deliberately play with the pen and ink. And the performance factors of any picture should be organically linked and have a role in expressing the theme of the work. If the performance factor on the screen does not play a good role, it will definitely play the opposite role.

\section{THE UNIQUE CHARM OF THE COMPOSITION}

\section{EXPRESSION TECHNIQUE IN THE ART LANGUAGE OF UNIQUE} SINO-RUSSIAN ICE AND SNOW PAINTING

The ice and snow painter would change various shapes, colors, and shades into different combinations for the composition expression technique in Sino-Russian unique ice and snow painting language. We will get a completely different emotional response through the composition. The painter often uses the lines to express the style of the ice and snow painter. These expressive lines are his brushwork. An ice and snow painter left his inner emotions and character's imprint on the ice and snow painting through expressive lines. Therefore, in the art creation of Chinese ice and snow painting, the method of expressing an emotion with simple lines is the traditional method. The lines include dotted lines and solid lines on the screen. They are hint lines. This is imaginary line. We can see it in famous Russian ice and snow painter Sidrov's ice and snow painting. The contours along the turning point are gone. However, in the artistic language, we still know the exact position of the outline. If you can have a starting point, an ending point, and some intermediate "road signs", the imagination usually fills these gaps. This allows the viewer to have the opportunity to participate in the creative process. The imaginative line will also enhance the surrounding atmosphere and the feeling of light. Also, it would give a sense of space. Lines can also express rhythm. And lines can mark the boundaries of space. They can express the boundaries of time. In other words, when your eyes move from this area to another area of ice and snow painting, the "tempo" you see is usually marked by the lines that cut off the parts. If there are quite a few lines to pass, the speed will slow down. Conversely, when your eyes are crossing flat color gamut, they are generally relatively faster. This rhythm factor can be guided by snow and ice painter to change the speed. And it would enhance the visual excitement. Another example is the color in the art creation of ice and snow painting, which can stimulate people's emotions very sensitively. Red and orange give people a warm feeling. Blue and green give people a cold feeling. After a long period of dark weather, when the warm sunshine first appears, it will give people a feeling of excitement and joy. The color in the art creation of ice and snow painting can achieve the same psychological effect in people's vision. Golden leaves mean autumn. Blue and white ice and snow would make people feel the coldness of winter. If you use black and white color to depict the rainbow and the setting sun, etc., it would lose its beauty.

In short, the special feelings and the satisfaction we get from the artistic creation of Sino-Russian ice and snow paintings are the same as the satisfaction we get from literary 
works. The special feelings caused by the creation of ice and snow paintings are also impossible for any other art. This kind of impression is produced by the certain arrangement of the color of ice and snow painting, the different structures of the line, and the changes of light and shadow. It was conceived by the ice and snow painter. With the unique artistic expression technique of the composition of the ice and snow painting, it would produce the painting that could be the music of the painting. In order to make the ice and snow paintings are valued art works, the ice and snow painter must give the ice and snow painting complete expression. The authenticity of the artistic ideas of ice and snow painting is manifested in the artistic language of ice and snow painting. It can be said that there is an inseparable dialectical relationship between language and thinking.

The study and reference of the composition and expression techniques of Sino-Russian ice and snow paintings is not only a matter of learning the rules of the artistic expression of ice and snow painting, structural skills and composition patterns, but also a problem that needs to strengthen the ideological exercise. The author has done some analysis on the beginners of the ice and snow painting art creation. When there are common problems, the idea does not find the inner connection of the materials, and the structure of the picture is loose. The picture ideas are indistinguishable. The structure is chaotic, and it lacks the overall sense of unity. If the thought leaves the subject of ice and snow painting art creation, the composition of the picture flows through the expression technique, which is often large and empty. Therefore, we learn and draw on the art composition expression techniques of ice and snow painting. In order to make the composition of ice and snow painting art composition well, we must look at it, think more, and seek knowledge. The art composition language of ice and snow painting should be accurate, refined and typical.

\section{THE ORIGINALITY OF ARTISTIC EXPRESSION TECHNIQUES OF SINO-RUSSIAN ICE AND SNOW PAINTING}

The content of Sino-Russian ice and snow painting restricts the expression of the works, and the expression technique in turn affects the expression of the content. The theme of art creation of ice and snow painting is creative and must be expressed in a unique artistic language. The originality of ice and snow paintings must find a unique way of expression. Without the originality of the subject ideas, there is no original expression technique. Otherwise, the content and performance techniques are separated.

For the creation of ice and snow painting, it is not just for composition. It is not to use Sino-Russian ice and snow painting as a kind of illustration of the theme, nor to play some new tricks on the composition. Such works are conceptualized or sensational. And they are all impossible to move people. The purpose of composition in the creation of ice and snow painting is to express the basic idea of the ice and snow paintings. Content and expression techniques should be uniform. The composition picture is determined according to the content of the creation. If the picture changes size, the content does not change. The composition is never exactly the same. Of course, we won't repeat the composition on a different size of paper, and we will rearrange the composition that fits the layout. When a painter wants to enlarge his snowscape composition on a formal canvas or a larger canvas, it is necessary to modify the image of his composition rather than simply fill the squares already on the canvas. Then, it would maintain its expressiveness. Otherwise, it is just mechanical repetition, and neglects the change in the shape and size of the composition of the ice and snow painting, which affects the expression of the creative content.

The artistic expression of Sino-Russian ice and snow paintings is the concrete expression of the artistic creation content. And it is the specific expression technique of ice and snow painting. If we regard composition as the sum of purely structural techniques, it is not the expression divorcing from the content. It is to confuse the expression and content. The art composition of Sino-Russian ice and snow painting is composed of two aspects, which is the unity of objective real life and the artist's subjective thought.

In our opinion, the content of Russian ice and snow painting doesn't exist outside the works of art. It is the reality that does not depend on the art works. It is reflected in the art works of ice and snow painting. As the subjective image of an objective world, it would exist in the reality of the art work. The art of Russian ice and snow painting is indeed a kind of expression of the human feelings of winter life reflected in the visual.

The expression technique of Chinese ice and snow painting and the special expression technique that reflects objective real life - the artistic image is different. The artistic image of Chinese ice and snow painting is unique expression of art reflecting winter life. That is to say, the art of Chinese ice and snow painting is characterized by the expression of the artistic image of ice and snow painting.

However, we cannot reverse it and regard the expression of the art of ice and snow painting as an artistic image. In the specific art of ice and snow painting, the artistic image appears as the unity of the content and expression techniques of ice and snow painting. In the specific art of ice and snow painting, it includes not only the theme of ice and snow, but also the theme, image and plot, which are the factors in the performance of the art works of ice and snow painting. Therefore, we must distinguish the expression techniques that vividly reflect the winter life and the expression techniques that reflect the artistic image content of the ice and snow painting by special material description means.

\section{CONCLUSION}

In summary, a young painter who creates ice and snow painting, don't hurriedly practice creation. The painters must carefully study and learn from the classical works of SinoRussian ice and snow painting, and improve the appreciation ability. At the same time, the painters should master the artistic expression techniques and skills of art creation of ice and snow paintings as soon as possible. Only by learning can we make achievements. An ice and snow painting would use the form of expression. This unique artistic expression is created for our senses to perceive or for people's imagination. 
And what they express is the human thoughts and feelings. With the introduction of China's "the Belt and Road", China and Russia are strengthening cooperation and cultural exchanges in politics, economy, art and other aspects. The related research on art expression techniques of Sino-Russian ice and snow painting has become the main subject of current Sino-Russian painting art creation.

\section{REFERENCES}

[1] Chen Luojia. Outline of Foreign Art History [M]. Southwest Normal University Press, 1995. 陈洛加.外国美术史纲要 $[M]$.西南师范大学 出版社, 1995.

[2] Sun Gang. A Series of Classic Teaching Plans - Painting Landscape $[\mathrm{M}]$. Anhui Fine Arts Publishing House, 2010. 孙纲.经典教案系列 从书一油画风景[M].安徽美术出版社, 2010.

[3] Kircer, Yu.M. Drawing and Painting: prakt. allowance [Text] / Yu.M. Kircer. -М .: Высш. Shk., 1972. - 270 с. Кирцер, Ю.М. Рисунок и живопись: практ. пособие [Текст] / Ю.М. Кирцер. -М.: Высш. шк., 1972. - $270 \mathrm{c}$.

[4] B. Manin. Russian landscape. M, 2000 В. Манин. Русский пейзаж. M, 2000 